
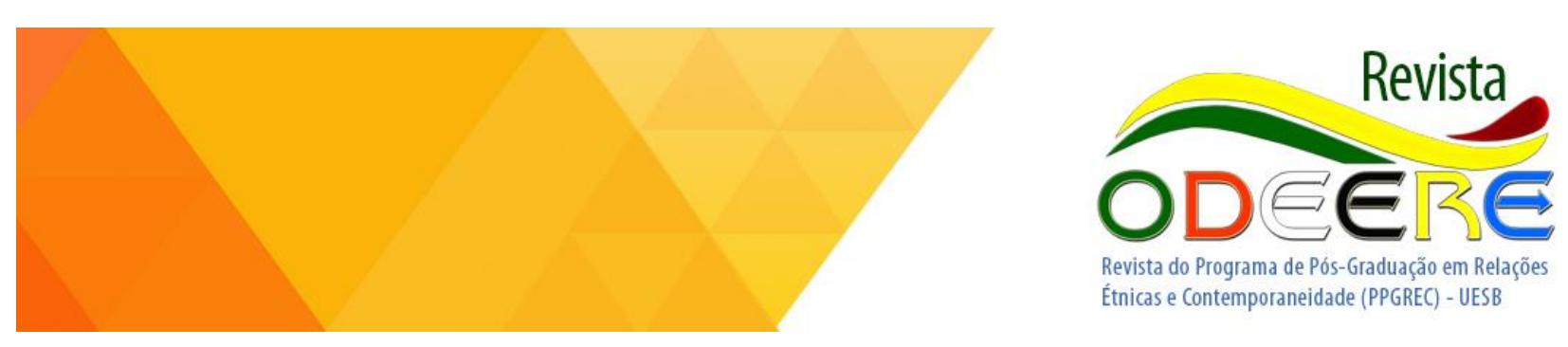

\section{Sexualidade, sensualidade e cultura ancestral}

\author{
Emanoel Luís Roque Soares \\ Universidade Federal do Recôncavo da Bahia \\ (UFRB) \\ el-soares@uol.com.br
}

Resumo: Este artigo fala sobre a influência das religiões sobre nossos corpos, primeiramente o catolicismo, que no pretexto de salvar almas bárbaras e hereges tentou catequizar os índios e os negros para domesticar seus corpos, e dos negros que trazem consigo uma forte cultura ancestral centrada no corpo para o Brasil. Durante a colonização e diáspora aconteceu um forte encontro cultural que construiu uma maneira própria de ser no mundo do afrodescendente. $O$ texto em si está fundamentado na mitologia, uma vez que o mito é a maneira primordial de ser no mundo e na cultura popular nas músicas de Carlinhos Brown e Clara Nunes. Discute sobre a sexualidade dos orixás, seu encontro na umbanda com os ciganos, falando de Maria Padilha, a rainha da sedução, que é um dos exus femininos mais populares. A sensualidade em pessoa, Maria Padilha vai fazer parte da umbanda e da maioria dos candomblés, sendo responsável pelos problemas de cunho amoroso. O texto aprofunda, também, conceitos como ancestralidade, comunicação cultural, inversão exuriana e identidade.
Palavras-Chave:

Comunicação

Sexualidade.
Ancestralidade, Cultural, Sensualidade, 
Sexuality, sensuality and ancestral culture

Abstract: This article talks about the influence of religions on our bodies, first the Catholicism that in the pretext of saving barbarian and heretic souls tried to catechize Indians and blacks to tame their bodies, and of the black people that bring with them a strong ancestral culture centered in the body for Brazil. During the colonization and diaspora happened a strong cultural encounter that constructed a proper way to be in the world of Afrodescendant. The text itself is based on mythology, since myth is the primordial way of being in the world and popular culture in the songs of Carlinhos Brown and Clara Nunes. He discusses the sexuality of the orishas, their meeting in umbanda with the gypsies, speaking of Maria Padilha, the queen of seduction, who is one of the most popular female exus. The sensuality in person, Maria Padilha will be part of umbanda and most candomblés, being responsible for the problems of love. The text also deepens concepts such as ancestry, cultural communication, exurian inversion and identity.

Keywords: $\quad$ Ancestry, Cultural Communication, Sensuality, Sexuality.

Bem antes de a escravidão começar nas Terras de Santa Cruz, nome como foi batizado o Brasil por Pedro Álvares Cabral logo após de sua chegada, já se tem registros de tráfico de escravos africanos para Portugal com a justificativa de humanizar e cristianizar grupos de bárbaros e hereges, uma vez que para eles tudo aquilo que estava fora do mundo europeu e, consequentemente, cristão era considerado não humano, selvagem e sem cultura.

Pode-se ler neste "humanizar" um adestrar de corpos e em "cristianizar" um submeter-se à religião católica para justificar a exploração da mão de obra escrava sem muita revolta. Começa ai uma comunicação cultural sem precedentes que vai fundir culturas, recriando e reinventando modos de serem iguais na diferença.

Nos mostra Waldeloir Rego ${ }^{1}$ que, com o crescimento do tráfico negreiro devido ao "espírito aventureiro do português" ${ }^{2}$ e sua ganância, esta influência cultural negra vai aparecer na cultura portuguesa, principalmente, em Lisboa, através das obras dos poetas, literatos e trovadores como

\footnotetext{
${ }^{1}$ REGO, Wedeloir in CARYBÉ, Os deuses africanos no candomblé da Bahia/Carybé, 2ed. Salvador, Biograf, 1993, p.183

2 IDEM
} 
Gil Vicente, Luís de Camões e Garcia Rezende, em paralelo a estas expressões culturais, os negros estão em todas as partes, ora como serviçais, ora como exotismo, de maneira que "a coisa cresceu tanto, que em pouco tempo já podia se sentir Lisboa com um cheiro de cidade mulata"3.

Também, nesta época, em virtude dos descobrimentos, vai surgir uma quantidade imensa de bulas papais que, em sua maioria, afirmam que tudo descoberto e conquistado, inclusive os escravos negros, pertencem ao rei católico de Portugal. Sendo assim, fica implícito o desejo e o apoio por parte da igreja ao Estado para converter tudo e todos ao catolicismo, sob o pretexto da civilidade e humanização que vai arrefecer as paixões, as sensualidades e sexualidades de tudo que o português cristão, através dos dogmas da sua fé, vai julgando como bárbaro e atrasado. Esse tudo está diretamente ligado ao que se refere ao corpo, ao humano e aos seus sentidos práticos, seu ser no mundo, seus desejos, formas de representações e suas lascívias.

O catolicismo, nesta época, vira sinônimo de humanidade e civilidade, colocando tudo e todos que não o segue na barbárie e fazendo parecer que a escravidão e submissão era um favor que os portugueses, sobre a égide da igreja, prestavam à humanidade.

Desta maneira, os traficantes de escravos, ganham apoio incondicional da santa igreja católica a "este negocio lucrativo" que vai se intensificar depois do suposto descobrimento do Brasil, em 22 de abril de 1500, quando na com a chegada de Cabral na Bahia de Todos os Santos, onde ele manda rezar a primeira missa simbolizando e formalizando a presença da santa Sé. Agora, a justificativa além de salvar almas bárbaras e hereges, vai estar somada a uma segunda, que diz, para colonizar o Brasil e tornar Portugal próspero era necessário uma mão de obra escrava. Entretanto, nos conta Pierre Verger:

A extraordinária resistência oposta pelas religiões africanas às forças de alienação e extermínio com que frequentemente se defrontava haveria de surpreender a todos aqueles que tentavam justificar a cruel instituição do trafico de escravos, com o argumento de que suas atividades - os dos negreiros - "constituíam o meio mais seguro e mais desejável de conduzir à igreja as almas dos negros, o que seria mais recomendável do que deixá-los na África, onde se perderiam num paganismo degradante ou estariam ameaçados pelo perigo da sujeição herética às

${ }^{3}$ IDEM

Odeere: revista do programa de pós-graduação em Relações Étnicas e Contemporaneidade - UESB. ISSN 2525- 4715. Ano 2, número 3, volume 3, Janeiro - Junho de 2017. 
nações estrangeiras, para onde seriam no mínimo, deploravelmente enviados". Era assim que se exprimiam os "Homens de Negócios da Bahia" [... $]^{4}$

O catolicismo é uma religião que serve muito bem para uma política escravista, uma vez que prega a resignação e está apoiada na dominação, através da catequese aplicada com muita eficiência por padres jesuítas, onde os prazeres do corpo, tais como sexualidade, comida, embriaguez, erotismo, dança, sensualidade e outros, principalmente, todos os deleites diretamente ligados ao corpo e ao humano, até mesmo o próprio riso, tornaram-se pecados luxuriosos.

A esta doutrinação catequista que é uma tentativa de submeter culturalmente o outro, o diferente, o não católico, vai servir como uma luva para submissão mais pacífica dos escravizados, evitando confrontos desnecessários, sempre arrefecendo as lutas, nunca as extinguindo, pois índios e negros em algumas situações vão lutar defendendo sua liberdade com a própria vida e, além disso, vai introduzir o sentido de pecado na vida destes povos, que antes tinham naturalidade e orgulho nas suas práticas corporais e nos prazeres sexuais, sem punições e ou restrições a todos os tipos de deleites corpóreos e sem nenhum sentimento de culpa, expondo com naturalidade sua sensualidade, valorizando o belo do corpo de cada um.

Nota-se que a primeira preocupação do colonizador português é cobrir o corpo dos escravos indígenas e depois dos escravos vindos da África. Porém, estas tentativas de adestramento dos corpos, de inversão de valores do cristianismo não foram muito bem sucedidas ou suficientes para conter a maneira de agir, fazer e de ser dos povos ancestrais vindos da África, no contato com os já existentes no Brasil (indígenas) e ou de culturas antigas europeias (ciganos), espíritas e até com os novos cristãos (protestantes) que se esconderam nos quilombos fugindo da perseguição católica catequista. Desta maneira, aconteceu uma grande comunicação cultural, que vai promover mudanças significativas na cultura de todos os envolvidos.

Podemos afirmar que existem dois tipos de mudança cultural: uma que é interna, resultante da dinâmica do próprio sistema cultural, e uma segunda que é resultado do contato de um sistema cultural com outro.

No primeiro caso, a mudança pode ser lenta, quase imperceptível para o observador que não tenha o suporte de bons dados diacrônicos. 0 ritmo, porém,

\footnotetext{
${ }^{4}$ VERGER,Pierre in CARYBÉ, Os deuses africanos no candomblé da Bahia/Carybé, 2ed.Salvador, Biograf, 1993,p.203.
} 
pode ser alterado por eventos históricos tais como uma catástrofe, uma grande inovação tecnológica ou uma dramática situação de contato.

O segundo caso, como vimos na afirmação do Manifesto sobre aculturação, pode ser mais rápido e brusco. No caso dos índios brasileiros, representou uma verdadeira catástrofe. Mas, também, pode ser um processo menos radical, onde as trocas culturais ocorrem sem grandes traumas. ${ }^{5}$

As marcas e alterações culturais deste encontro foram regidas, primeiramente, pelas diversas formas de resistências destes povos, da cultura e mesmo pela filosofia contida no interior da religião ancestral africana que iria ampliar-se em um contato sincrético com outros povos, uma vez que a formação cultural do povo no Brasil tem no seu cerne uma transformação que advém da troca de comunicação entre pensamentos diferentes de três povos (africano, indígena e português).

Sendo o ato de comunicar-se uma das principais características do orixá Exu, aquele que se comunica e muda ao receber da cultura alheia e produz mudanças ao ceder da sua cultura ao outro "muda e se transforma, mistura-se, comunica-se, torna novamente, mudando-se com o outro, pertencendo-se e identificando-se, princípio ativo da vida - o próprio movimento em si." ${ }^{6}$

Esta característica mutante e aderente já é inerente aos diversos povos de África (que tem Exu em seus princípios religiosos). Agora, é amplificada com os encontros entre outras culturas e outros povos na diáspora. Devido à sua natureza agregadora, interventiva e antropofágica de apropriar-se do que tem de positivo e importante proveniente da cultura alheia.

Exu, além destas características citadas acima é o orixá da sensualidade, da sedução e da sexualidade. É representado por um falo ereto, coisa que muito constrangeu aos cristãos, que não o compreendiam e, mesmo na ignorância, o execrava, a ponto de compará-lo, para depreciá-lo, com o demônio da seita judaica cristã, ou o compreendia muito bem e sabiam que ele era o centro da religião dos Orixás, pois segundo a uma máxima do candomblé "sem exu não se faz nada" e por isso, da mesma forma sempre tentaram depreciá-lo.

O segundo fator que devemos evidenciar é o aparecimento no Brasil das irmandades que haviam sido criadas por Gregório I, visando popularizar a igreja, conseguindo a maior quantidade

\footnotetext{
${ }^{5}$ LARAIA, Roque de Barros. Cultura: um conceito antropológico. 17. ed. Rio de Janeiro: Jorge Zahar, 2004, p.96.

${ }^{6}$ SOARES, Emanoel Luís Roque. As vintes faces de Exu na filosofia afro descendente da educação. Coleção UNIAFRO, Crus das Almas, EDUFRB, 2016. p.88
}

Odeere: revista do programa de pós-graduação em Relações Étnicas e Contemporaneidade - UESB. ISSN 2525- 4715. Ano 2, número 3, volume 3, Janeiro - Junho de 2017. 
de pagãos, adeptos leigos para santa igreja, ele introduz na mesma o culto das imagens, que de certa forma vai ser bem mais permissivo às festas aos corpos (danças, músicas, folguedos, etc.) uma espécie de profano no interior do sagrado. Agora, o adepto vai ter uma relação direta como a imagem do santo sem a antiga transcendência ao espiritual, não exigindo erudição e estudo para adentrar na igreja.

Aqui está clara a inversão, uma vez que a irmandade foi criada para conter os ânimos, arrefecer e acomodar as almas sobre a égide do cristianismo colonizador consolidando a escravidão passa ela ser o local de onde os negros vão clamar por liberdade. Tal inversão é recíproca, pois neste movimento os sujeitos trazem consigo seu mundo existencial, deslocando-o na figura do outro seu confrade livre branco que, às vezes, fazia parte da mesma irmandade, no caso das mistas, onde brancos e negros conviviam juntos ou em irmandades puramente de negros que requeriam o status igual o das puramente brancas. $^{7}$

Quando os negros começam a participar das confrarias e, assim, a revindicar todos os direitos do cristão liberto para si e para os outros alforriando-se, passam a ter cidadania e liberdade de espírito a ponto de recriarem no interior das confrarias uma nova maneira de cultuar orixás, que é o que hoje conhecemos como candomblé, onde corpo, dança, canto, encenação lúdica e conto trazem com toda força a sexualidade e sensualidade para a cultura afrodescendente.

O interessante e importante neste processo é compreendermos ai o intervertimento de maneira exuriana que se apropria do melhor do que existe na cultura alheia dando sentido próprio ao estrangeiro, recriando-se, reiniciando-se com o outro, mantendo sua identidade ancestral que é sempre múltipla, mutante e igual na diferença.

Tal identidade manifesta-se não como uma igualdade do que já foi, ou como algo igual a si mesmo ao que era no passado, mas como algo que mudou durante um caminho. Isto afirmo não no sentido da lógica ocidental, mas como algo diverso e inverso que é diferente, que não segue o princípio onde $A=A$, e sim onde $A$ é igual ao "ser sendo" e à sua própria metamorfose, pois A transformou-se no percurso. Ela, a identidade, é igual à ancestralidade tomando a forma de comum pertencimento, em que eu não sou igual aos meus antepassados, mas sim me transformei no caminho e no tempo, porém continuo pertencendo, fazendo parte de um conjunto de princípios que mudaram, se misturaram, inovaram, mas têm

\footnotetext{
${ }^{7}$ Ibid.,p. 99.
} 
as mesmas matrizes ontológicas que o formaram, tornando-se igual na diferença e mantendo características importantes na forma de ser. ${ }^{8}$

Tanto no candomblé como na umbanda os ancestrais têm características humanas, carregam em si todas as idiossincrasias do humano mortal, sente o que nós sentimos, ou melhor, nós sentimos o que eles sentem, somos parecidos na diferença, temos características tanto fenotípicas como espirituais em comum na nossa essência, uma vez que são eles nossos antecessores. Por exemplo, um filho de Ogum se comporta mentalmente como o deus da guerra, carrega consigo o arquétipo do orixá e possui características no andar e na postura corporais idênticas entre si.

Sendo Exu um movimento, força energia vital dos corpos, dinamismo ancestral em constante devir, fica evidente e se torna importante e imprescindível ressaltar que Exu se transformou ao chegar, tanto no Brasil como em outros lugares, onde houve diáspora ao se encontrar com as outras culturas já acima citadas, com as quais foi dialogando, apropriando-se e mudando, uma vez que o devir constante faz parte das características deste orixá, que é a força dinâmica coletiva e individual, a força de todos os seres, sendo circular. Exu é o pai da fertilidade, da embriaguez e da sedução e todas as passagens de estágios da vida estão diretamente ligadas a este orixá.

Ele é principio, meio e fim em si mesmo e esta característica proporcionou a aparição aqui no Brasil de seu par feminino. Talvez, seja a maneira mais exacerbada da sexualidade e sensualidade exuriana, que são a Pomba Gira e Maria Padilha, mulheres que bebem, dançam, fumam, riem alto, vestem-se com extravagância, são sedutoras e amam, que provavelmente, sugiram do encontro dos negros com ciganos, indígenas e portugueses no Brasil, uma vez que não se encontram registros delas em África.

Do que temos registro é de ter chegado aqui na Bahia o culto a lya Mapo "patrona da Vagina" de Ibejiti $^{9}$ e da historia de Ifá que faz parte do Odu Osa Meji falando da colocação da vagina na mulher, que foram escolhidos vários lugares até chegar onde hoje ela está (meio das pernas), o que nos prova que a sexualidade e a sensualidade acompanham os ancestrais vindos da

\footnotetext{
8 Ibid.,p.88.

${ }^{9}$ REGO, Wadeloir in CARYBÉ, Os deuses africanos no candomblé da Bahia/Carybé, 2ed. Salvador, Biograf, 1993REGO, p.184
} 
África, onde sempre existiu uma preocupação com o corpo e tal preocupação vai se ampliar no encontro com os outras culturas, no caso de Padilha, vinda da cultura cigana.

Os ciganos chegam ao Brasil em 1534 como degredados com Martim Afonso de Souza, segundo Maria Elena Farelli ${ }^{10}$ e com eles vem a Ciganinha Poerê, cigana ancestral que bebe champanhe, fuma, gosta de vestir-se suntuosa e sedutoramente. Ela reina absoluta na Umbanda da linha do oriente onde existe a junção de outras culturas, uma vez que a umbanda é uma religião ancestral, genuinamente brasileira, que melhor sintetiza nossa formação cultural, mostrando esta mistura.

Provavelmente, estes ciganos se encontraram com os negros nos quilombos, uma vez que o quilombo tem a natureza acolhedora africana e recebia tudo que era excluído pelo colonizador e por isso acolhem esta ancestral espanhola, cigana oriunda da mitologia antiga da Europa e perseguida pelos católicos, que passara a figurar na umbanda e no candomblé.

\begin{abstract}
Durante séculos, a igreja lotou para afastar essas lendas da mente do povo, entretanto, as sibilas romanas e pitonisas gregas nunca foram abandonadas pela religião popular. Sem perceber, o povo recria mitos e lendas, incorporando heranças milenares em seus conteúdos. Na Itália, no inicio da idade moderna, ainda existia o culto a Príapo, Deus fálico e lascivo, que era adorado nas aldeias e que rivalizava com as doutrinas ocidentais. Até hoje, nos grandes centros urbanos, vivem as videntes, mágicas, adivinhas e cartomantes, todas as mulheres predestinadas que podem ver o futuro. ${ }^{11}$
\end{abstract}

Desta forma, Maria Padilha, rainha da sedução, é um dos exus femininos mais populares. Ela é a sensualidade em pessoa que vai fazer parte da umbanda e da maioria de candomblés e é responsável diretamente pelos problemas de cunho amoroso. É ela quem "ata e desata" os relacionamentos com os mais diversos nomes (Sete Saias, Maria Molambo, Maria Rosa, entre outros) sendo ponto central da polêmica da "pureza nos candomblés" uma vez que os candomblés ditos puros da Bahia (Ilê Axé Iyá Nassô Oka, Cantois, Ilê Opó Ofunjá) acusam as casas onde se cultuam Padilha, Pomba Gira e até mesmo os caboclos de umbandomblés ou candomblés de caboclo.

\footnotetext{
${ }^{10}$ FARELLI, Maria Helena. Pomba-Gira cigana, Rio de Janeiro, Pallas,2006

${ }^{11}$ Idem., p.13.
}

Odeere: revista do programa de pós-graduação em Relações Étnicas e Contemporaneidade - UESB. ISSN 2525- 4715. Ano 2, número 3, volume 3, Janeiro - Junho de 2017. 
Nas festas de Umbanda a rainha Pomba Gira Cigana recebe presentes colares, bebidas e rendas para enfeitar suas saias. Nos cultos negros do Haiti, realizados a porta do cemitério, uma figura recebe um culto especial e os cânticos mais alegres: e a mulher do demônio, eterna deusa da volúpia e do pecado. E nosso passado sensual retorna em plena era espacial, na figura do demônio de saias, a milenar senhora da luxuria e da alegria... ${ }^{12}$

Segundo Prandi, tanto no candomblé como na umbanda, Pombagira recebe inúmeras denominações entre as quais Pombagira das Almas, das Mangueiras, Maria Quitéria, Menina das Sete Encruzilhadas, entre outras. "Pombagira é especialista notória em casos de amor e tem poder para propiciar qualquer tipo de união amorosa e sexual"13.

É evidente que o universo da sexualidade e sensualidade pertence a Exu, porém esta nação do corpo que ama, dança, canta, dos relacionamentos, da reprodução, que seduz e é seduzido, que deseja e é desejado, que trai e é traído perpassa por toda ancestralidade, uma vez que como já foi dito neste ensaio o principio identitário que une os humanos aos seus ancestrais é o da igualdade na diferença.

Carregamos arquétipos, temos semelhanças e estamos embebidos na cultura da qual somos descendentes, pertencentes, de maneira que fica evidente esta sensualidade ancestral nos lugares onde as forças da diáspora atuaram na sua plenitude máxima, a exemplo de Salvador na Bahia onde esta sensualidade pode ser vista por toda a cultura em suas diversas maneiras de manifestação, tais como música, artes plásticas, dança teatro, festas populares, bem como, nos comportamentos carregados de sensualidades do povo soteropolitano que se expressam na fala como os diminutivos carinhosos usados por amantes ao se referir aos seus mais velhos e, até mesmo, na própria maneira de andar que valoriza a maleabilidade do corpo ancestral.

Para melhor exemplificarmos como estas características ancestrais submetem nossos corpos nas suas maneiras de ser e estarem no mundo, recorreremos ao mito, uma vez que neles estão guardados as verdades sobre um povo, descrevendo com veracidade a essência de cada cultura. Conta o mito que:

Ogum vivia com Oiá

Um dia seu irmão Xangô foi visitá-lo

e, na casa de Ogum, Xangô deparou com sua bela mulher.

\footnotetext{
12 Ibdi.,p.14.

${ }^{13}$ PRANDI, Reginaldo.Segredos Guardados: Orixás na alma brasileira, São Paulo: Companhia das Letras, 2005, p.86.
} 
Voltou para casa atormentado pela beleza que vira.

Desejou Oiá ardentemente.

Não desistia da ideia de possuir a mulher de seu irmão.

Xangô voltou à casa de Ogum

dizendo-se doente, nem conseguia se alimentar.

Ogum o acudiu-o pediu-Ihe que ensinasse a Oiá

O preparo de seu prato predileto, o amalá

que sem duvida saciaria a fome e o curaria.

Oiá preparou o amalá conforme ensinado.

Antes de comê-lo,

Xangô pediu para Oiá acrescentar um pó,

advertindo-a contudo que não provasse da comida.

Xangô comeu com gula e saciou a fome.

A proibição deixou Oiá muito curiosa.

No dia seguinte, Oiá fez novamente a comida,

mas não resistiu e provou dela.

Disse a Xangô não ter sentido nada especial.

Xangô entregou-Ihe o pó para acrescentar.

O pó tinha o poder de botar labaredas pela boca.

Oiá pôs o pó no amalá e comeu dele.

Desde então Oiá tem o poder de botar fogo pela boca.

Ogum ao ver sua mulher cuspindo fogo,

repudiou Oiá e a entregou a Xangô.

Xangô cinicamente recusou a oferta.

Ogum insistiu para que levasse Oiá dali.

Xangô tinha enganado Ogum,

Xangô levou Oiá para casa,

feliz com sua vitória ${ }^{14}$

Notamos que, no mito o desejo não é pecado mesmo em si tratando da mulher do irmão e que a beleza e a atração incontida é uma normalidade para os Orixás que não se submetem à moral católica, que reza em um dos seus mandamentos o não desejo da mulher do próximo, a conquista vai se dá através da "boca" do paladar, da comida, consequentemente do corpo, a maneira ardilosa encontrada por Xangô para ter em seus braços Oiá não contem violência e nem mesmo Ogum, o deus da guerra, tem a passionalidade violenta ocidental.

A comunicação entre mítica cultura ancestral africana e as outras já citadas, vai se desdobrar na cultura afrodescendente, de maneira tal que diversas canções e manifestações culturais vão versar sobre o assunto fazendo parte assim do imaginário de um povo que agora não

\footnotetext{
${ }^{14}$ PRANDI, Reginaldo. Mitologia dos Orixás. São Paulo: Companhia das Letras, 2001, p.93.
} 
é somente um e, sim, o plural, através da comunicação cultural onde a sexualidade e sensualidade estarão juntas e passa de tempos e de povos, através da música, mito, poesia e da comunicação.

Assim sendo comunicação é um processo cultural. Mais explicitamente, a linguagem humana é um produto da cultura, mas não existiria cultura se o homem não tivesse a possibilidade de desenvolver um sistema de articulado de comunicação oral. ${ }^{15}$

A primeira canção que mostraremos é da compositora e intérprete Clara Nunes (1942 a1983) carioca umbandista:

IANSÃ

lansã, Cadê Ogum?

Foi pro mar!

Mas lansã, Cadê Ogum?

Foi pro mar!

(3x)

lansã penteia

Os seus cabelos macios

Quando a luz da lua cheia

Clareia as águas do rio

Ogum sonhava

Com a filha de Nanã

E pensava que as estrelas

Eram os olhos de lansã

Mas lansã, Cadê Ogum?

Foi pro mar!

(2x)

lansã, Cadê Ogum?

Foi pro mar!

(2x)

Na terra dos orixás

Um amor se dividia

Entre um deus que era de paz

E outro deus que combatia

Como a luta só termina

${ }^{15}$ LARAIA, Roque de Barros. Cultura: um conceito antropológico. 17. ed. Rio de Janeiro: Jorge Zahar, 2004, p.52.

Odeere: revista do programa de pós-graduação em Relações Étnicas e Contemporaneidade - UESB. ISSN 2525- 4715. Ano 2, número 3, volume 3, Janeiro - Junho de 2017. 


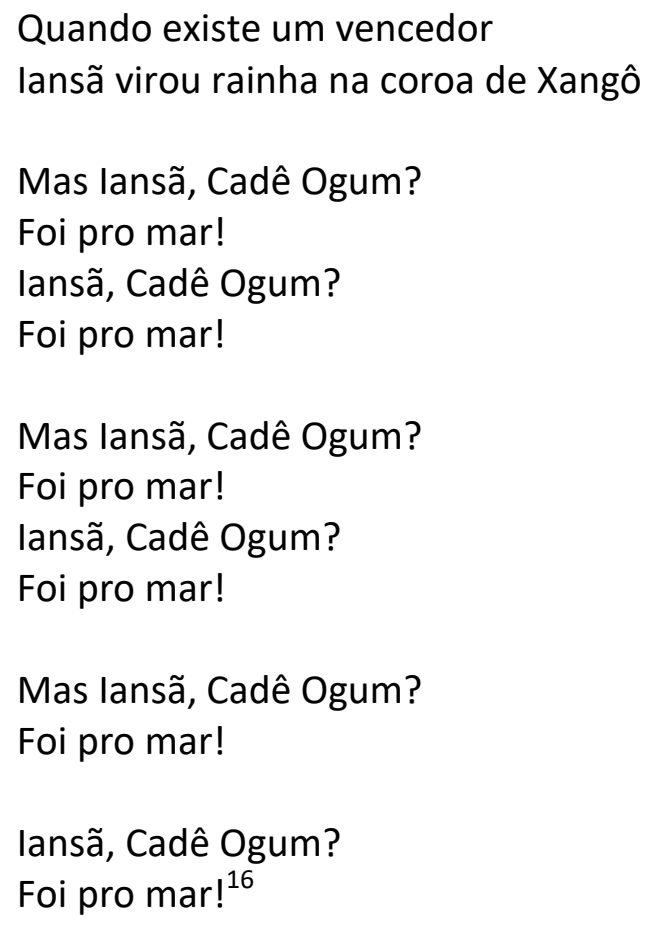

Nossa artista fala da vaidade feminina da iabá (orixá feminina) que penteia seus cabelos e da contenda entre os dois orixás na disputa do amor e atenção de lansã ou Oiá como é conhecida, na música e poesia de Clara.

Estão contidas, também, para além da sensualidade da iabá, outras características como a da mãe de lansã que é Nanã, a mãe do mundo e a mais velha das iabás; o arquétipo de Ogum, o deus da guerra; da sua paixão por Oiá e seu retiro para o mar, casa de sua mãe lemanjá, depois da desilusão amorosa.

Destaca, também, a coroa de Xangô, o rei de Oyo, ao lado de Oiá, onde suas ações eram de justiça. Daí a artista refere-se a ele como o deus da paz.

"Prestar a atenção que o amor se dividia" quer dizer que o amor é dos dois, que lansã tem dois amores o que vai aparecer em outros mitos. Esta possibilidade seria uma perversão para o catolicismo onde a mulher é submissa ao homem sem a mínima possibilidade de aceitação do adultério feminino, uma vez que, além de ser uma cultura que nega o corpo hipocritamente, ainda é machista, fazendo vistas grossas ao adultério masculino muito comum, desde o Brasil colônia até os tempos atuais.

\footnotetext{
${ }^{16}$ Ver: https://www.vagalume.com.br/clara-nunes/iansa.html acesso em 19 de abril de 2017
} 
Na segunda música Ginga de Balé, do compositor baiano Carlinhos Brown e Buzziga, intérprete da banda Timbalada, a poesia vai versar sobre uma filha de Oiá exemplificando que as características dos orixás passam para seus filhos, uma vez que a ancestralidade, como aqui já foi dito, é nada mais que a igualdade na diferença. Desta maneira, as músicas são iguais na diferença, uma vez que a primeira fala da orixá Oiá e a segunda, de uma de suas filhas, cabendo aqui ressaltar a similaridade sensual e sexual de ambas.

\author{
GINGA DE BALÉ \\ (Carlinhos Brown / Buzziga) \\ O que trança na cabeça \\ dessa beldade negra \\ fino traço é o retrato \\ de uma deusa ginga \\ ginga o corpo sem defeito \\ com direito \\ só pra mostrar quem é \\ herdeira dos deuses \\ da soberania africana \\ é filha de Yansã balé \\ no barco só navega um \\ carente de um terreiro egum \\ foi namorada de Xangô \\ e se desentendeu com oxum \\ agora é mulher fiel \\ é a mona do Ocam \\ do ferro azulado do rei Ogum \\ babaulere \\ babaulere \\ bada balera yaô babá \\ tchu dhiubi dhiubi dhiubi \\ bada bada bada badaba \\ babaulere \\ babaulere \\ bada balera yaô babá ${ }^{17}$
}

${ }^{17}$ Ver: https://www.vagalume.com.br/timbalada/ginga-de-bale.html acesso em 19 de abril de 2017

Odeere: revista do programa de pós-graduação em Relações Étnicas e Contemporaneidade - UESB. ISSN 2525- 4715. Ano 2, número 3, volume 3, Janeiro - Junho de 2017. 
Carlinhos Brown vai falar da beleza e sensualidade da filha de lansã, de sua ginga, do seu corpo e cabeça, além de destacar os fundamentos da deusa senhora dos eguns (mortos), herdeira de ocam de Ogum, o deus do ferro, e do desentendimento de Oiá com Oxum, a deusa da beleza, da sedução e a mulher que consegue tudo que quer, seduzindo, encantando, usando seu corpo. Também é a deusa da fertilidade e da maternidade; um de seus instrumentos (ferramentas) é o abébé, espelho onde a deusa narcisa não se cansa de olhar sua beleza sedutora. A sua cor é o amarelo ouro e, já que falamos dela, vale a pena lembrarmos de um mito onde a deusa seduz o próprio Exu.

Quando Oxum quis aprender o jogo dos búzios recorreu a Exu, a quem agradou com seu jeito manso de mulher bonita e delicada, que tem como características arquetípicas a generosidade, doçura e persuasão, proveniente das mães, atributos estes que seduziram agradavelmente a Exu, e este terminou ensinando o jogo do Ifá à Orixá contrariando a promessa que tinha feito a Orunmilá que era de não ensinar a ninguém, principalmente, às mulheres, para as quais o poder da antevisão era vetado. Antes, somente, quem jogava eram os homens consagrados Orunmilá, o senhor dos Oráculos, e a Exu, sendo que os consagrados a Exu tinham aprendido e adquirido o poder de vislumbrar o futuro, através de concessão feita pelo vidente, pois fora Exu que havia ajudado Orunmilá a ganhar diretamente das mãos de Olodumaré estes poderes, antes pertencentes a Xangô que preferira guerrear aos atos adivinhatórios.Quando questionado por babá Orunmilá sobre a quebra do sigilo Exu manhosamente responde que havia ensinado a Oxum jogar ao contrário. Desta maneira, foi criada por Exu uma outra forma de ver o real, o mesmo jogo ao contrário, ou seja, as mulheres veem a realidade e, principalmente, anteveem o mundo às avessas, elas veem de uma outra maneira, forma que é extremamente necessária para a concepção cosmogônica do mundo africano, e que através da característica que tem Exu de inverter as coisas, de tornar do erro um acerto, isto é, de um dos seus arquétipos que vêm à tona a partir do mito que nos foi contado de forma carinhosa e risonha pela famosa Ialôrixa Stela de Oxóssi, zeladora maior do Ilê Axé Opo Afonjá. ${ }^{18}$

No mito aparece o quanto é natural para o africano usar a sensualidade sem culpas para conseguir o que quer e, também, notamos o poder feminino que não é tão destacado em outras culturas. Podemos ver que a mitologia ligada aos orixás, a poesia e a músicas sempre se referem a beleza, sensualidade libertada do sentimento cristão do corpo pecador. Na música de Brown que envolveu os três orixás, sem culpa e sem mágoa ou mesmo referência ao pecado da religião cristã, os corpos estão livres para os desejos.

\footnotetext{
${ }^{18}$ SOARES, Emanoel Luís Roque. As vintes faces de Exu na filosofia afro descendente da educação. Coleção UNIAFRO, Crus das Almas, EDUFRB, 2016,p.96.
}

Odeere: revista do programa de pós-graduação em Relações Étnicas e Contemporaneidade - UESB. ISSN 2525- 4715. Ano 2, número 3, volume 3, Janeiro - Junho de 2017. 
No sincretismo católico na Bahia, lansã é santa Barbara, muito adorada pelos amantes e homossexuais, veste vermelho a cor da paixão e é a patrona do corpo de bombeiros (diretamente ligada ao fogo de Xangô e a bravura do guerreiro Ogum). É uma mulher de dois homens que em vários outros mitos demonstra toda a sua sensualidade e sexualidade e que deu a luz a nove filhos, tamanho é o seu apetite sexual.

No pantheon dos orixás encontramos também Oxumaré, representado na natureza pelo arco-íris. Usa colares de contas verdes e amarelo e quando estão dançando seus filhos apontam, ora para terra, ora para o céu, alternadamente. $\mathrm{O}$ arquétipo de seus filhos, segundo Pierre Fatumbi Verger é:

Oxumaré é o arquétipo das pessoas que desejam ser ricas; das pessoas pacientes e perseverantes nos empreendimentos e que não medem sacrifícios para atingir seus objetivos. Suas tendências à duplicidade podem ser atribuídas à natureza andrógena de seu deus. Com o sucesso tornam-se facilmente orgulhosas e pomposas e gostam de demonstrar sua grandeza recente. Não deixam de possuir certa generosidade e não se negam a estender a mão em socorro à aqueles que dela necessitam. ${ }^{19}$

Para Oxumaré, tudo é mudança em sua vida e na vida dos filhos. Deste orixá não poderia ser diferente, tanto podem mudar de casa, lugares como de amigos, negócios, seus amores e humores estão em constante e radical devir. Talvez, por isso, Ihes seja atribuído o poder característico da bissexualidade de seus filhos, se atraem por mulher ou homem de forma natural, sem preconceitos. Dizem ser o Orixá meta-meta (metade homem metade mulher), que passam seis meses mulher e seis meses homem.

Oxumarê usurpa a coroa de sua mãe Nanã

Oxumarê era filho de Nanã.

No seu destino estava escrito que ele deveria ser seis meses um mostro e seis meses uma linda mulher.

Aos poucos, a mulher de Oxumarê revoltou-se com a mãe, pois não conseguia nunca uma relação de amor estável.

Quando estava tudo bem com ela e seu amante, ela virava mostro e afastava o companheiro. Um dia Oxumarê encontrou-se com Exu.

Exu semeou um conflito maior entre o Arco-iris e a velha Nanã.

Exu convenceu Oxumarê que a velha deusa deveria pagar

\footnotetext{
${ }^{19}$ VERGER, Pierre Fatumbi.Orixás, Tradução de Maria Aparecida Nóbrega. 6a ed., Salvador: Corrupio, 2002. P. 207.
} 
pelos males que atormentavam o seu filho.

Exu aconselhou Oxumarê

a tomar a coroa da nação jeje, que pertencia a Nanã.

Oxumarê foi ao palácio de Nanã

e aterrorizou a todos na sua forma de serpente.

Nanã suplicou-lhe que não matasse ninguém,

tentando dissuadi-lo de seu objetivo.

Mas acabou entregando a Oxumarê sua coroa

e Oxumarê foi coroado rei dos jejes. ${ }^{20}$

Fica expresso aqui no arquétipo deste orixá o não preconceito ancestral às diversas formas de expressão sexual. Esta maneira de ver o mundo livre dos pecados do corpo físico vai permitir que todas as formas sexuais do ser do humano transitem livremente no mundo do candomblé, podendo o adepto da religião dos orixás, além de frequentar, ascender ao mais alto cargo da casa de santo, sem importar sua sexualidade, que só é contida, momentaneamente, nos períodos de obrigação do terreiro, uma vez que somente quando se cumpre com as obrigações o corpo físico entra em resguardo corpóreo.

A cultura do corpo permeia toda a ancestralidade. É ele o corpo que move nossas vontades e idiossincrasias nos remetendo diretamente ao nosso ancestral. Podemos notar, também, que na comunicação cultural nos transformamos e deixamos de ser o africano, o europeu ou o indígena e transformamos no brasileiro fruto desta mistura. Somos o novo com identidade no passado e estamos para além das determinações de cada época e em constante devir somos o corpo, sexo e sensível que muda em constante vir a ser.

Do que até aqui foi visto podemos concluir que:

A ancestralidade é uma descendência contínua, é a igualdade na diferença daqueles que nos antecederam, carregamos juntos conosco o arquétipo de nosso antecessor que antes de ser transformado em orixá por Olorum eram homens como nós, suas lembranças tanto no corpo (fenótipo) como no espírito é algo vindo de tempos longínquos.

São nas lembranças míticas de seus feitos que nos reconhecemos, diz Verger:

Um babalaô me contou:

"Antigamente, os orixás eram homens,

Homens que se tornaram orixás por causa de seus poderes.

Homens que se tornaram orixás por causa de sua sabedoria.

\footnotetext{
${ }^{20}$ PRANDI, Reginaldo. Mitologia dos Orixás. São Paulo: Companhia das Letras, 2001, p.227.
} 
Eles eram respeitados por causa de sua força.

Eles eram venerados por causa de suas virtudes.

Nós adoramos sua memória e os altos feitos que realizaram.

Foi assim que estes homens tornaram-se orixás.

Os homens eram numerosos sobre a terra.

Antigamente, como hoje,

Muitos deles não eram valentes nem sábios,

A memória deles não se perpetuou.

Eles foram completamente esquecidos;

Não se tornaram orixás.

Em cada vila, um culto se estabeleceu

Sobre a lembrança de um ancestral de prestigio

As lendas foram transmitidas de geração em geração,

para render-lhes homenagem" ${ }^{21}$

A cultura afrobrasileira é fruto de uma enorme comunicação cultural, forçada na diáspora escravista entre africanos, índios, portugueses e outros povos europeus, entre os quais os ciganos que, aqui vieram como degredados expulsos da corte portuguesa nos trouxeram sua Maria Padilha para formar o casal com Exu que, aqui no Brasil, ganhou sua versão fêmea.

Exu é o orixá representado pelo falo ereto que simboliza a fertilidade e sexualidade entre os humanos e também responsável pela comunicação entre culturas. Aberto para dar e receber, sempre se apropriando do que de melhor encontra na cultura alheia.

Está no cerne da cultura ancestral a noção de corpo de sensualidade e sedução, como forma de ação e de ser no mundo, para o africano tudo passa pelos sentidos e todas as maneiras de amor e prazer corpóreo tem o seu valor, sem preconceito em relação as maneiras sexuais de ser de cada um dos orixás ou mesmo dos seus filhos.

Os portugueses tentaram impor, via catequese, uma maneira cristã de negar o corpo, introduzindo o pecado na mente dos africanos e indígenas para arrefecer seus extintos e melhor escravizá-los, porém esta tentativa aparentemente não logrou sucesso, os mesmos portugueses trouxeram sem querer e sem saber das consequências as irmandades que vão possibilitar que os negros se encontrem em um só espaço e tornem-se irmãos capazes de recriar uma religião ancestral.

\footnotetext{
${ }^{21}$ VERGER, Pierre Fatumbi. Lendas africanas dos orixás, Tradução de Maria Aparecida Nóbrega. 4ạ ed., Salvador: Corrupio, 1997, p.9.
}

Odeere: revista do programa de pós-graduação em Relações Étnicas e Contemporaneidade - UESB. ISSN 2525- 4715. Ano 2, número 3, volume 3, Janeiro - Junho de 2017. 
Não só a religião ancestral foi recriada aqui no Brasil, como também a religião católica foi afetada de maneira que os cantos de louvor ganharam uma intensidade digna da afrodecendência, também os evangélicos neopentecostais ganharam vários elementos da cultura ancestral, durante seus cultos os evangélicos de diversas igrejas dançam, cantam e até recebem o espírito santo, da mesma maneira que uma filha de santo incorpora seu orixá.

Desta forma, o cristianismo após o contato cultural comunicativo com umbanda e candomblé também se transformou, adquirindo manifestações que valoriza e libera os corpos e seus sentidos. Observando em New Orleans, onde a diáspora também foi intensa, durante as cerimônias fúnebres os membros da igreja evangélica dançam e cantam, fazendo uma intensa coreografia, que de certa maneira lembra o ritual fúnebre do candomblé, o axêxê, onde os adeptos cantam e dançam por sete dias e sete noites, dependendo da importância ritual do morto.

Esta intensa comunicação cultural nos torna especiais, para além do que somos, uma vez que não fechamos um campo, nem totalmente do lado católico, nem totalmente do lado do culto aos orixás africanos. Encontramos nosso próprio e apropriado caminho, o candomblé onde o corpo reina e reinam também as espiritualidades, onde sexo não é pecado e ser sensual é uma tarefa para o corpo que aprende a dançar, comer, cantar e rir dos outros e de si próprio, onde a maneira sexual de ser de cada um não determina sua função ou poder dentro de uma sociedade, onde comida é prazer e não pecado, diminuindo com certeza as anomalias causadas pela repressão sexual e preconceitos impostos por uma religião racista e sexista que nega o corpo e sua sensualidade, mas isso é uma outra história.

\section{Referências Bibliográficas}

CARYBÉ, Os deuses africanos no candomblé da Bahia/Carybé, 2ed.Salvador, Biograf, 1993.

FARELLI, Maria Helena. Pomba-Gira cigana, Rio de Janeiro, Pallas,2006

LARAIA, Roque de Barros. Cultura: um conceito antropológico. 17. ed. Rio de Janeiro: Jorge Zahar, 2004.

PRANDI, Reginaldo. Mitologia dos Orixás. São Paulo: Companhia das Letras, 2001.

Odeere: revista do programa de pós-graduação em Relações Étnicas e Contemporaneidade - UESB. ISSN 2525- 4715. Ano 2, número 3, volume 3, Janeiro - Junho de 2017. 
Letras, 2005.

. Segredos Guardados: Orixás na alma brasileira, São Paulo: Companhia das

SOARES, Emanoel Luís Roque. As vintes faces de Exu na filosofia afro descendente da educação. Coleção UNIAFRO, Crus das Almas, EDUFRB, 2016.

VERGER, Pierre Fatumbi. Lendas africanas dos orixás, Tradução de Maria Aparecida Nóbrega. 4ạ ed., Salvador: Corrupio, 1997.

Orixás, Tradução de Maria Aparecida Nóbrega. 6ạ ed., Salvador:

Corrupio, 2002.

https://www.vagalume.com.br/clara-nunes/iansa.html acesso em 19 de abril de 2017.

https://www.vagalume.com.br/timbalada/ginga-de-bale.html acesso em 19 de abril de 2017.

Emanoel Luís Roque Soares: Professor associado I ensina de filosofia da educação e filosofia da ancestralidade da Universidade Federal do Recôncavo da Bahia, Centro de Formação de Professores, Amargosa-BA, também é professor permanente do mestrado profissional em Historia da África da UFRB. Participa dos seguintes grupos de pesquisa: NÚCLEO DE PESQUISA FILOSÓFICA: EDUCAÇÃO, EPISTEMOLOGIA E POLÍTICA (líder) além do NIHME/UFC e HCEL/UFBA. Tem a seguinte formação: Pós-doutor em Educação Universidade Federal da Paraíba/FACED (2012) Doutor em Educação (2008) Universidade Federal do Ceará/FACED. Mestre em Educação (2004) Universidade Federal da Bahia/FACED. Especialista em Estética, Semiótica, Cultura e Educação (2001): Universidade Federal da Bahia/FACED. Bacharel em Filosofia (1999): Universidade Católica do Salvador. Discuti os seguintes temas: filosofia da ancestralidade, filosofia da educação e formação do professor de filosofia, memoria do negro no Brasil e religiões de matriz africana.

Artigo recebido para publicação em: Fevereiro de 2017.

Artigo aprovado para publicação em: Junho de 2017.

Odeere: revista do programa de pós-graduação em Relações Étnicas e Contemporaneidade - UESB. ISSN 2525- 4715. Ano 2, número 3, volume 3, Janeiro - Junho de 2017. 